\title{
Inactivation of Extracellular Laccase During Fruiting of Agaricus bisporus
}

\author{
By D. A. WOOD \\ Glasshouse Crops Research Institute, Rustington, \\ Littlehampton, West Sussex BN16 3PU
}

(Received 11 June 1979)

The decline in activity of extracellular laccase of Agaricus bisporus which occurs during fruit body development was shown to be due to both enzyme inactivation and proteolysis. Extracts of high activity, from cultures during mycelial growth, and of low activity, from cultures during fruiting, remained unchanged on prolonged incubation and did not crossactivate or inhibit on mixing. No activity changes occurred after dialysis, gel filtration or ultrafiltration of both forms. Molecular weights, $\mathrm{pH}$ optima, substrate specificities and immunological properties of the two forms were identical. Differences were found in the electrophoretic profiles of the two forms of enzyme. Loss of enzyme activity was shown to be greater than loss of enzyme protein by separate immunological and electrophoretic methods.

\section{INTRODUCTION}

During growth of the mycelium of the edible mushroom Agaricus bisporus on wheat straw compost, large quantities of extracellular laccase are produced (Turner, 1974; Wood \& Goodenough, 1977). During the development of the first crop of fruit bodies there is a rapid five- to tenfold decrease in laccase activity. The use of axenically fruited cultures and of mutant strains of $A$. bisporus showed that this change in laccase activity was due to the fungus itself and, furthermore, it could be correlated with fruit body enlargement (Wood \& Goodenough, 1977). Other examples have also been reported in which changes in the activity of extracellular laccase have been correlated with basidiomycete fruit body formation (Philips \& Leonard, 1976). No detailed study has yet been made of the properties of such enzymes before and after these activity changes, or on the likely mechanism of inactivation.

It has been suggested that the nutritional pattern of the mycelium of $A$. bisporus undergoes a shift from the preferential utilization of lignin and protein polymers during mycelial growth to cellulose and hemicellulose utilization when fruiting is initiated (Gerrits, 1969). Loss, or change in the properties, of various enzymes is a common occurrence in many organisms which are undergoing metabolic shifts either as a result of nutrient limitation or differentiation (Thurston, 1972; Switzer, 1977). The present investigation shows that the loss of activity of extracellular laccase of $A$. bisporus during fruiting is due partly to an irreversible inactivation and partly to proteolysis. The properties of the two forms of the enzyme are described and the possible mechanisms of inactivation are discussed.

\section{METHODS}

Organism. Agaricus bisporus strains D621 and D649 were used. These are fertile heterokaryotic strains currently used for mushroom production in the U.K.

Media and culture. The strains were grown in wheat straw compost in large wooden trays by normal 
commercial methods. For a description of the preparation of the growth substrate and subsequent colonization and fruiting by $A$. bisporus, see Tschierpe \& Sinden (1964).

Preparation of enzyme extracts. Samples of mycelium-colonized compost $(50 \mathrm{or} 100 \mathrm{~g})$ were taken $25 \mathrm{~d}$ after inoculation when laccase activity was near maximal (Wood \& Goodenough, 1977). Further samples were taken $40 \mathrm{~d}$ after inoculation when the first crop ('flush') of fruit bodies had been removed from the trays. Samples were taken only from the underlying compost layer, taking care to exclude material from the overlying layer of peat-chalk mixture (casing layer) used to induce fruiting. The compost samples were mixed with $0.01 \mathrm{M}$-phosphate buffer $\mathrm{pH} 7.0$, shaken, filtered and centrifuged as previously described (Wood \& Goodenough, 1977). The final supernatants containing laccase activity were normally stored at $-20^{\circ} \mathrm{C}$ until required. Up to five cycles of freezing and thawing had no effect on enzyme activity.

Enzyme assays. Laccase activity was assayed as previously described using $p$-phenylenediamine as a substrate (Wood \& Goodenough, 1977). One unit of laccase is defined as the amount catalysing the consumption of $1 \mu \mathrm{mol} \mathrm{O} \mathrm{O}_{2} \mathrm{~min}^{-1}$. Protease activity was assayed with the insoluble substrate Remazol Brilliant Blue-hide powder conjugate, as previously described (Wood \& Goodenough, 1977). One unit of protease is defined as the amount catalysing the solubilization of $1 \mu \mathrm{g}$ dye $\mathrm{min}^{-1}$.

Electrophoresis. Electrophoresis of enzyme-containing extracts was carried out using both non-denaturing and denaturing [sodium dodecyl sulphate (SDS)] acrylamide gel columns as previously described (Wood, 1980). Protein staining and localization of enzyme activity were as previously described (Wood, 1980).

To obtain samples for SDS-polyacrylamide electrophoresis, several sub-samples (50 $\mu 1$ each) of high and low activity extracts were electrophoresed in non-denaturing $7.5 \%(\mathrm{w} / \mathrm{v})$ polyacrylamide gels. After staining one gel of each activity to localize the enzyme, the corresponding area of the remaining gels was excised. The slices were eluted with $0.01 \mathrm{M}$-phosphate buffer $\mathrm{pH} 7.0$ and samples were tested for purity by electrophoresis on non-denaturing gels. No non-enzymically staining bands were found. The eluate was freeze-dried and then taken up in a small volume $(200 \mu \mathrm{l})$ of denaturing mixture and boiled. The denatured extract was electrophoresed on SDS-polyacrylamide gels and stained as previously described (Wood, 1980).

The amount of laccase protein present in stained bands was estimated densitometrically. After staining and destaining, the gels were placed in glass tubes and loaded into an Isco gel scanning apparatus (M.S.E., Crawley, Sussex) connected to an Isco absorption monitor. This was set to absorb at $620 \mathrm{~nm}$ and was in turn connected to a chart recorder. After scanning, the individual chart peaks were cut out and weighed to provide a value for the protein present in a stained band in the gel. The weight of the peaks was plotted against the quantity (volume or enzyme units) of enzyme loaded on to the gel; this gave a linear relationship for loadings up to $150 \mu \mathrm{g}$ enzyme protein. A similar relationship was found when samples of purified bovine serum albumin were electrophoresed.

Immunological methods. Double diffusion and immunoelectrophoresis were carried out using the methods and antiserum previously described (Wood, 1980). To measure the amount of laccase protein in compost extracts, a radial immunodiffusion method was used (Mancini et al., 1965). Anti-laccase serum at 1/20 or $1 / 50$ dilution in saline was incorporated into molten $1.5 \%(\mathrm{w} / \mathrm{v})$ immunodiffusion agar and standard volumes $(14 \mathrm{ml})$ were poured into $9 \mathrm{~cm}$ diam. Petri dishes on a level bench. A suitable spaced pattern of holes was punched in the agar with a $4 \mathrm{~mm}$ diam. cork borer. Compost extracts containing different amounts of enzyme activity were introduced into the wells and mixed with sterile saline to give a final volume of $40 \mu \mathrm{l}$. After incubation at $25^{\circ} \mathrm{C}$ for $36 \mathrm{~h}$ the diameters of the resulting precipitin rings were measured. A plot of the logarithms of initial volume of extract versus precipitin ring diameter was linear for both high and low activity extracts. A similar procedure was carried out using samples of purified enzyme of known protein concentration (Wood, 1980). The antigen concentration in the unknown sample was then obtained from this standard curve.

Chromatographic procedures. Samples of compost extract previously dialysed for $24 \mathrm{~h}$ in two changes of $0.01 \mathrm{M}$-phosphate buffer $\mathrm{pH} 7.0$ were applied to the top of columns $(1.5 \times 30 \mathrm{~cm})$ of DE52 ion-exchange cellulose (Whatman). The columns were washed and eluted with a linear gradient of sodium chloride in 0.01 M-phosphate buffer as previously described (Wood, 1980). Concentrated extracts prepared over Amicon ultrafiltration membranes (PM10) were eluted through columns of Sephadex G-25 or G-100. The molecular weights of high and low activity forms of the enzyme were obtained from a Sephadex column previously calibrated with proteins of known molecular weight (Wood, 1980).

\section{RESULTS}

\section{Stability of enzyme activity}

After preparation, batches of high and low activity extracts were passed through sterile membrane filters $(0.22 \mu \mathrm{m}$ pore size $)$ and stored in sterile bottles at $25{ }^{\circ} \mathrm{C}$. At intervals 
Table 1. Enzyme recovery after treatments which might remove diffusible inhibitors and activators

$\begin{array}{lcc}\text { Treatment } & \overbrace{\begin{array}{c}\text { High } \\ \text { activity } \\ \text { enzyme }\end{array}}^{\begin{array}{c}\text { Low } \\ \text { activity } \\ \text { enzyme }\end{array}} \begin{array}{c}\text { Percentage of initial } \\ \text { activity recovered }\end{array} \\ \text { Dialysis for 36 h against 0.01 M-phosphate pH 7.0 } & 99 & 98 \\ \text { Ultrafiltration through PM10 membrane } & 98 & 95 \\ \text { Gel filtration on: } & 96 & 90 \\ \text { (i) Sephadex G-100 } & 95 & 92 \\ \text { (ii) Sephadex G-25 } & & 95\end{array}$

samples were removed and enzyme activity was measured. No significant change in activity was found in either high or low activity extracts over $7 \mathrm{~d}$. Repeated freezing and thawing also had no effect. Omission of the membrane filtration step allowed dense bacterial populations to develop in the extracts, but no effect on enzyme activity was found.

\section{Tests for the presence of a diffusible inhibitor or activator}

To determine if either high or low activity extracts could modify the activity of the other they were mixed in a 1:1 ratio and incubated for $7 \mathrm{~d}$. There was no significant crossactivation or inhibition on mixing, nor did the activity of the extract alter over the $7 \mathrm{~d}$. Each extract was also treated in various ways which should remove any weakly bound inhibitors or activators. Extracts were dialysed for $36 \mathrm{~h}$ in several changes of $0.01 \mathrm{M}$ phosphate buffer $\mathrm{pH} \mathrm{7.0}$; no change in activity was found, with most of the initial activity being recovered (Table 1). The extracts were also ultrafiltered with similar results (Table 1). When high and low activity preparations were passed through columns of Sephadex G-25 and G-100, again virtually all the activity initially loaded on the column was recovered (Table 1).

\section{Electrophoretic properties}

High activity extracts showed several distinct enzymically active bands which corresponded to similar bands staining for protein (Fig. $1 a$ ). Laccase appeared to be the major protein in the extracts. Low activity extracts also showed laccase activity in a similar zone of the gel but as a diffuse band. The protein staining of low activity extracts of laccase showed diffuse bands of protein (Fig. 1b). In addition the low activity extracts contained several non-enzymically active protein bands (Fig. $1 b$ ).

In SDS-polyacrylamide gels, the high activity enzyme was resolved into five bands of molecular weights 56600, 46000 (doublet band), 39000, 31000 and 21000 (Fig. 2b). The 56600 polypeptide was the most densely staining band. The molecular weights of the enzyme polypeptides approximated to those found for the purified culture filtrate enzyme (Wood, 1980). The low activity band had a different profile (Fig. 2c). Bands of 63100 (doublet), $58000,50000,39000$ and 37000 molecular weight were found with no band being particularly prominent.

\section{Immunological properties}

In double diffusion tests with anti-laccase serum, both forms of the enzyme gave a single precipitin band which was continuous and non-overlapping, indicating immunological identity. The two forms were also tested by immunoelectrophoresis; only a single precipitin arc was formed. When the two forms were co-electrophoresed on a single acrylamide gel column and tested against antiserum, only a single arc was formed. 


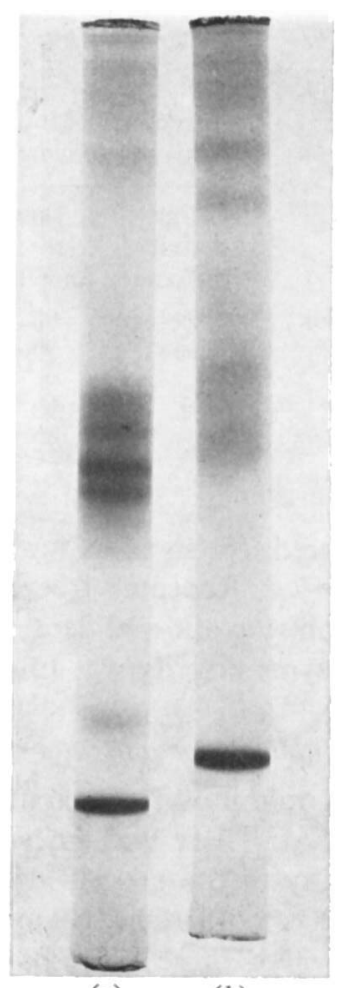

(a)

(b)

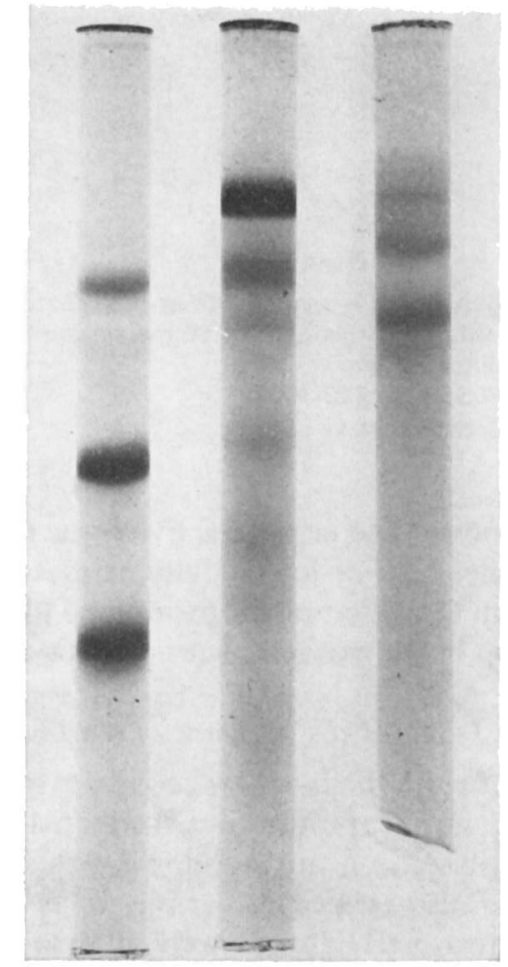

(b)

(c)

Fig. 1. Polyacrylamide gel electrophoresis on $7 \cdot 5 \%$ polyacrylamide gels of high activity $(a)$ and low activity $(b)$ extracts of laccase from $A$. bisporus. Both gels stained for protein. Laccase activity corresponds to the bands in the central region of the gel. The origin is at the upper end of each gel. Marker dye (bromophenol blue) is the lowest band.

Fig. 2. Sodium dodecyl sulphate-polyacrylamide gel electrophoresis of purified denatured high activity $(b)$ and low activity $(c)$ laccase preparations from $A$. bisporus. The marker gel $(a)$ contained the following molecular weight standards (from top to bottom): ovalbumin (43000), carbonic anhydrase (29000) and myoglobin (17200). The origin is at the upper end of each gel.

\section{Other properties}

The $\mathrm{pH}$ optimum of both high and low activity forms of the enzyme was at $\mathrm{pH} 5 \cdot 6$; the $\mathrm{pH}$-activity profiles were identical when tested with $p$-phenylenediamine as the substrate and both were similar to the profile found for the extracellular enzyme produced on cultures grown in malt extract medium (Wood, 1980). The pattern of substrate specificity of the two forms was the same and both oxidized substrates similar to those oxidized by the culture filtrate enzyme (Wood, 1980). The Michaelis constant was the same for both activity forms when using $p$-phenylenediamine as the substrate. Molecular weights estimated by gel filtration on Sephadex G-100 columns were identical at around 100000 (Fig. 3). The shapes of the elution profiles were virtually identical (Fig. 3). The high and low activity forms gave identical profiles on elution from ion-exchange cellulose columns.

\section{Quantity of enzyme protein in extracts}

To determine whether loss of enzyme activity was due to loss of enzyme protein by degradation, the amount of enzyme protein in the extracts was estimated by two separate methods. Since laccase was the major protein observed in electrophoretic separation on 


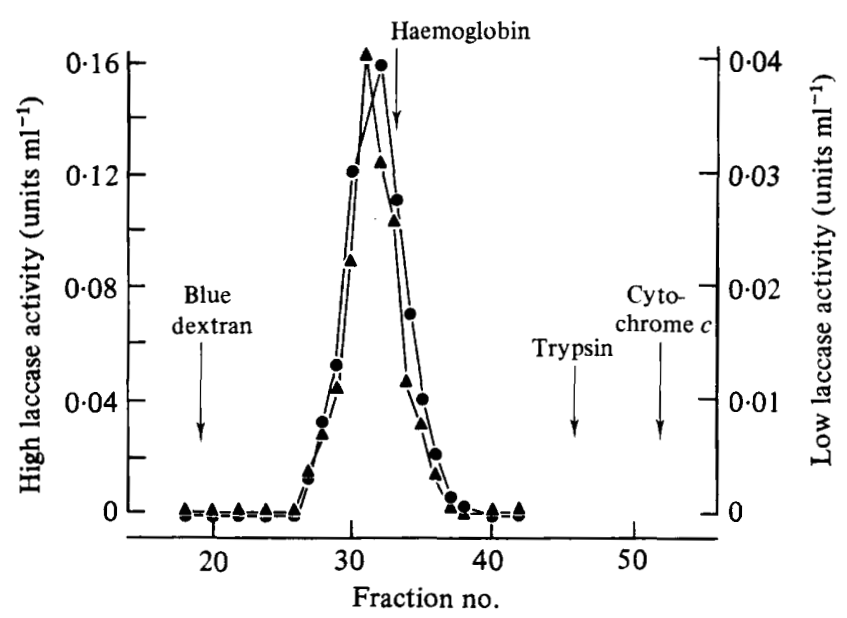

Fig. 3. Gel filtration of high activity $(\boldsymbol{\Delta})$ and low activity $(\boldsymbol{)})$ laccase of $A$. bisporus on Sephadex G-100. Gel filtration was performed as described in Methods.

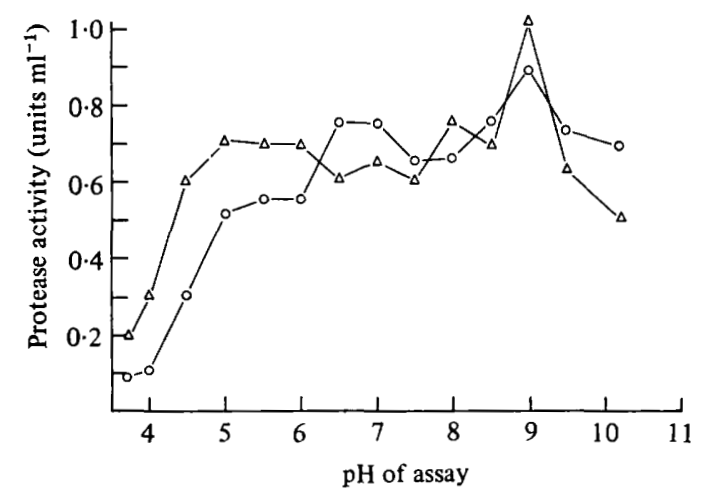

Fig. 4. pH-activity profile of protease activity extracted from compost colonized by mycelium of A. bisporus: $\bigcirc$, before fruiting at $25 \mathrm{~d} ; \triangle$, after fruiting at $40 \mathrm{~d}$.

non-denaturing acrylamide gels and was well separated from other proteins (Fig. 1), different amounts of the two extracts with known activity were electrophoresed on separate gels and, after staining, the resulting bands were scanned by densitometry and the amount of laccase protein was estimated in terms of the peak area. The results showed that the low activity extracts contained only 25 to $30 \%$ laccase protein per unit volume compared with the high activity extracts. In addition, from the amount of laccase loaded and from the weights of the peak areas from the recorder charts, specific activities could be calculated for both extracts. These were 0.0870 and 0.0288 units (g chart paper) ${ }^{-1}$ for the high and low activity extracts, respectively, i.e. a ratio of 3.02 to 1 . In the initial extracted samples the ratio of high to low activity was $9 \cdot 8$ to 1 .

A separate estimate on the same extracts as used for electrophoresis was made using a radial immunodiffusion method. From the standard curve prepared with the purified enzyme the amount of cross-reacting protein in both extracts was estimated. The low activity extracts contained only 25 to $30 \%$ cross-reacting protein per unit volume compared with the high activity extracts. Again, specific activities were calculated for each extract. These were 13.1 and 3.7 units (mg protein) $)^{-1}$ for the high and low activity extracts, respectively, i.e. a ratio of 3.5 to 1 . 


\section{Protease activity of extracts}

To determine if the change in activity of laccase at fruit body development coincided with increased extracellular protease activity, measurements were made of protease activity in both extracts over a wide $\mathrm{pH}$ range. The results (Fig. 4) showed that the $\mathrm{pH}$-activity profiles of the two types of extract were very similar and that there was no large increase in activity at any particular $\mathrm{pH}$ value.

\section{DISCUSSION}

In contrast to the published findings on Schizophyllum commune (Philips \& Leonard, 1976), no evidence was found in this study to show that regulation of the activity of the extracellular laccase of $A$. bisporus could be accounted for by the production of diffusible inhibitors from the mycelium. The mixing experiments and the virtually complete retention of enzyme activity on passage of both high and low activity extracts through Sephadex columns, or on treatment by dialysis or ultrafiltration, indicated that if a diffusible inhibitor were responsible for the observed decline in activity it must either be unstable, and presumably reversible in effect, or very tightly bound to the enzyme. There are precedents for enzyme activity to be regulated by the tight binding of an inhibitor (Losada, 1974). Since the enzyme extracts were very stable and low activity extracts showed no reactivation on incubation or mixing with high activity preparations, a tightly bound inhibitor would be more likely to account for activity loss. To show the presence of such a compound will require the production and purification of large quantities of enzyme of both forms. The molecular weights of the two forms were apparently identical and, even allowing for the likely error in molecular weight estimation by the use of gel filtration, such an inhibitor would have to be of fairly low molecular weight (about 4000 or less).

The extracellular laccase produced by $A$. bisporus in compost retains its full activity on prolonged incubation at room temperature. It would seem unlikely, therefore, that the decline in activity which occurs during fruiting is due to the inherent instability of the enzyme.

Decline in activity at fruiting might be due to cessation of laccase synthesis or excretion accompanied by normal or an increased rate of enzyme turnover. The rate of turnover of laccase protein in compost is not known and since the fungus can only be fruited on this medium the rate cannot yet be obtained. Two pieces of evidence suggest that the decline in activity is not due to turnover. Firstly, when compost-grown cultures are not treated with casing soils to induce fruiting, laccase activity remains high and does not subsequently decline, indicating that the normal turnover rate is very slow (Wood \& Goodenough, 1977). Similar results are found when the fungus undergoes nutrient limitation on malt extract medium (Wood, 1980). Secondly, the enzyme co-exists with one or more extracellular proteases but is not inactivated. Further evidence that the primary cause of inactivation is not proteolysis comes from the data on the molecular weights and immunological properties of high and low activity forms showing that they are identical. Nevertheless, enzyme protein does disappear since the low activity extracts contained only about one-third of the cross-reacting protein of the high activity extracts.

In other systems where enzyme inactivation occurs it has not always proved possible to obtain an in vitro system which mimics the processes of in vivo inactivation (Thurston, 1972; Switzer, 1977). The number of examples of extracellular enzyme inactivation that have been studied is very small. In one recent example involving the extracellular $1,3-\beta$-glucanase of basidiomycete QM 806 (Friebe \& Holldorf, 1975), it was found that protein bands on polyacrylamide gels corresponding to glucanase protein were lost when glucanase-producing cultures were shifted to glucose medium, and that the cross-reacting protein in double diffusion tests against enzyme antibody was also lost. It was suggested that loss of both protein and enzyme activity were concomitant, although no values were given for specific 
activity of active and inactivated enzyme. In addition, it was found that inactivation was controlled by an extracellular factor the production of which was sensitive to blockage of protein synthesis.

These findings differ from those for the $A$. bisporus laccase where loss of activity and protein are not concomitant and the only modifications found are in the profile of the enzyme protein on non-denaturing and denaturing polyacrylamide gels. This may indicate that the primary event which occurs during inactivation is an irreversible inhibition. This, in turn, may be followed by a slower rate of protein degradation. Since the specific activity of the low activity form is threefold lower than that of the high activity form, whereas $\mathrm{pH}$ optima and substrate specificities are similar, the putative inhibition is of a non-competitive type. The modification in electrophoretic profiles may result from very limited proteolysis or from modification of the glycan moiety, since the enzyme is a glycoprotein (Wood, 1980). Such degradation apparently produces little change in molecular weight. Again, to examine these suggestions large batches of purified enzyme will be required.

Selective inactivation of enzymes, defined as the irreversible loss in vivo of catalytic activity in the physiologically significant reaction of an enzyme, can be considered an important control of enzyme activity in micro-organisms (Switzer, 1977). The evidence presented here indicates that the loss of activity of extracellular laccase of $A$. bisporus can be considered in this category. Activity loss was due to both enzyme inhibition and enzyme degradation. The activity that remains, the low activity form, has many characteristics similar to those of the high activity form and is altered in others such as electrophoretic properties. Possible reasons for the occurrence of a selective enzyme inactivation at this stage in the life-cycle may be either that the products of enzyme activity are in some way inhibitory to fruit body development or that a nitrogen recycling mechanism is necessary, involving reassimilation of degraded enzyme protein. Laccase is the major excreted protein and accounts for $2 \%$ of the mycelial protein (Wood, 1980). Fruit body development may require extra nitrogenous material over that which can be supplied by the mycelium and hence extracellular protein including laccase may be degraded. The products of this degradation could be assimilated and then translocated to the developing sporophore.

I should like to thank Mr Stephen Matcham for his invaluable technical assistance. I am indebted to Dr C. Thurston, Queen Elizabeth College, London, for advice and criticism.

\section{REFERENCES}

Friebe, B. \& Holldorf, A. W. (1975). Control of extracellular $\beta$-1,3-glucanase activity in a basidiomycete species. Journal of Bacteriology 122, $818-825$.

Gerrits, J. P. G. (1969). Organic compost constituents and water utilised by the cultivated mushroom during spawn run and cropping. Mushroom Science 7, 111-126.

LoSADA, M. (1974). Interconversion of nitrate and nitrite reductase of the assimilatory type. In Metabolic Interconversion of Enzymes, pp. 257270. Edited by E. H. Fischer, E. G. Krebs, H. Neurath \& E. R. Stadtman. New York: Springer Verlag.

Mancini, G., Carbonara, A. O. \& Heremans, J. F. (1965). Immunochemical quantitation of antigens by single radial immunodiffusion. Immunochemistry 2, 235-254.

Philips, L. E. \& LeONARD, T. J. (1976). Extracellular and intracellular phenoloxidase activity during growth and development in Schizophyllum. Mycologia 68, 268-276.
SWITZER, R. L. (1977). The inactivation of microbial enzymes in vivo. Annual Review of Microbiology 31, 135-157.

Thurston, C. F. (1972). Disappearing enzymes. Process Biochemistry 7, 18-20.

TSCHIERPE, H. J. \& SinDEN, J. S. (1964). Weitere Untersuchungen über die Bedeutung von Kohlendioxyd für die Fruktifikation des Kulturchampignon Agaricus campestris var. bisporus (L) Lge. Archiv für Mikrobiologie 49, 405-425.

TURNER, E. M. (1974). Phenoloxidase activity in relation to substrate and development stage in the mushroom Agaricus bisporus. Transactions of the British Mycological Society 63, 541-547.

Wood, D. A. (1980). Production, purification and properties of extracellular laccase of Agaricus bisporus. Journal of General Microbiology 117, 327-338.

Wood, D. A. \& Goodenough, P. W. (1977). Fruiting of Agaricus bisporus. Changes in extracellular enzyme activities during growth and fruiting. Archives of Microbiology 114, 161-165. 